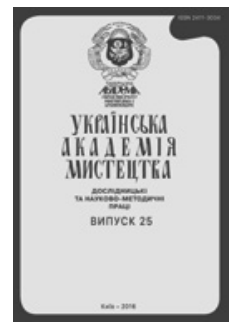

№27 (2018) стор. 44-49

The National Academy of Fine Arts and Architecture

Ukrainian Academy of Fine Art. Research and Methodology Papers

ISSN 2411-3034

Website: http://naoma-science.kiev.ua/

\title{
УДК 7.01
}

ORCID ID: 0000-0002-0628-146X

DOI: https://doi.org/10.33838/naoma.27.2018.44-49

\section{Світлана Оляніна}

кандидат архітектури, доцент кафедри графіки

Видавничо-поліграфічного інституту

НТУУ «Київський політехнічний інститут ім. І. Сікорського»

s.olianina@ukr.net

\section{АРХІТЕКТУРНЕ ОБРАМЛЕННЯ В ІКОНОСТАСІ ЯК ІНСТРУМЕНТ КОМЕНТАРЯ САКРАЛЬНОГО ОБРАЗА}

\begin{abstract}
Анотація. У статті розглядається арочна конструкція обрамлення ікон апостольського ярусу, яка з’явилася в українському іконостасі на початку XVII cm. Простежено традицію оформлення візантійських темплон і балканських іконостасів арковими обрамленнями та ї̈ зв'язок з введенням аркатури в оздоблення апостольського ярусу українського іконостаса. Визначена змістовна складова мотиву аркатури та ї̈ значення в осмисленні ярусу апостолів.
\end{abstract}

Ключові слова: іконостас, аркатура, обрамлення, смисл.

\section{АРХИТЕКТУРНОЕ ОБРАМЛЕНИЕ В ИКОНОСТАСЕ КАК ИНСТРУМЕНТ КОММЕНТИРОВАНИЯ САКРАЛЬНОГО ОБРАЗА.}

Светлана Олянина

Аннотация. В статье рассматривается арочная конструкция обрамления икон апостольского яруса, которая появляется в украинском иконостасе с начала XVII в. Прослежена традиция оформления византийских темплонов и балканских иконостасов арочными обрамлениями и ее связь с введением аркатурь в убранство апостольского яруса украинского иконостаса. Определена смысловая составляющая мотива аркатуры и ее значение в осмыслении яруса апостолов.

Ключевые слова: иконостас, аркатура, обрамление, смысл.

\section{ARCHITECTURAL FRAMING IN THE ICONOSTASIS AS AN INSTRUMENT OF COMMENTING ON THE SACRED IMAGE.}

Svitlana Olianina

Summary. Before the seventeenth century, the icons in the Ukrainian iconostasis did not have frames as an arch or a blind arcade. The epistyles with images of Deesis of fourteenth - sixteenth century have not frames at all or the figures are divided by the rectangular pictorial frames. However, from the beginning of the seventeenth century, the icons of apostles in a Deesis row had already framing by carved frames like as the blind arcade. This practice quickly spreads and becomes the rule for the representation of apostles at the iconostasis throughout the seventeenth century. The Christian origins of tradition to decorate sacral images by blind arcade to be continue from Byzantium. It is very important that this design of the icons is characteristic of the Byzantine templons. The epistyles of templons 
from the twelfth - fifteenth century are mostly framing by blind arcade. The same principle of decoration is passed to the Balkans, where the blind arcade also is fixed in the design of the Deesis row.

I argue that the blind arcade in the Ukrainian iconostasis in the design of the Deesis row comes from the Balkans The introduction of frames in the form of a blind arcade for icons of the Deesis row created compositional parallels between Ukrainian iconostasis and the iconostasis of the Balkans. This unity of the used compositional formulas reinforced the relationship of the Ukrainian iconostasis with the Balkan, and visually showed its Byzantine origins. On the basis of artistic and written sources, I demonstrate that blind arcade emphasized the eschatological meanings of the Deesis row. It was also a kind of marker that indicated the presence of this row in the multilevel structure of the monumental Ukrainian iconostasis of the seventeenth century.

Keywords: iconostasis, blind arcade, framing, meaning.

Постановка проблеми. Від початку XVII ст. ікони апостольського ярусу в українському іконостасі обрамлюються півциркульними арками, які утворюють довгі аркатури праворуч і ліворуч від центральної ікони. Цей прийом є нововведенням для облямування ікон іконостаса в Україні, однак він відразу стає загальноприйнятим і використовується як найбільш поширений варіант оформлення протягом усього XVII ст. Джерела запозичення аркатури та причини її появи в українському іконостасі залишаються нез'ясованими.

Актуальність дослідження. Архітектурні конструкції українських іконостасів XVII-XVIII ст. традиційно вивчаються з позиції стилю, який осмислюється як першопричина трансформацій їхнього художнього образу. Такий підхід пояснює зміни в композиції і пластиці іконостасів необхідністю узгодити архітектуру іконостаса з вимогами домінуючої естетичної концепції. Водночас заміщення в іконостасі одних форм іншими прив'язується до процесу оволодіння майстрами художньою мовою того чи іншого стилю. Безсумнівно, стиль $є$ одним з найважливіших факторів впливу на архітектуру іконостасів, але його значення не можна перебільшувати. Стилістичний підхід залишає поза увагою безліч інших аспектів, в тому числі історичних, культурних, смислових, які вплинули на формування архітектоніки і пластики вівтарних огорож православного світу. Сказане дозволяє подивитися на причини розвитку архітектоніки іконостаса 3 іншої точки зору, перемістивши стиль до вторинних факторів впливу і висуваючи на перше місце символічний задум. На наш погляд, зміна образності іконостаса відбувалася не від зміни стилю, а від зміни ідей. I тут ключову роль відіграли як богословський, так і культурно-історичний контекст, які в своїй сукупності визначали задум конкретного іконостаса, а відтак були основною причиною виникнення нових проектів іконостасів. Тож пошук відповіді на питання про смисл введення нових елементів оформлення в іконостас XVII ст. і джерела їхнього запозичення є необхідною умовою дослідження історії формування українського іконостаса.

Мета. Виявити джерела, що вплинули на появу аркового обрамлення ікон в іконостасі, та розкрити смисл такого оформлення в іконостасі.

Зв'язок авторського доробку 3 важливими науковими та практичними завданнями. Український іконостас $є$ одним з найяскравіших виразів української ідентичності, тому проблематика його походження і розвитку знаходиться в центрі уваги багатьох дослідників східнохристиянської культури. Однак грунтовне вивчення українського іконостаса як мистецького і культурного явища лише розпочинається і чимало питань потребують відповідей.

Аналіз досліджень. Дослідження українського іконостаса здебільшого присвячені аналізові його живописної програми, тоді як архітектурно-пластична організація залишається найменш вивченим його аспектом. Окремі особливості архітектурно-пластичного опорядження іконостаса XVII-XVIII ст. в контексті розвитку українського декоративно-прикладного мистецтва і скульптури торкалися у своїх роботах В. Александрович, М. Гембарович, В. Вуйцик, М. Станкевич, О. Тищенко. Сдиною фундаментальною працею, в якій широко розглянуто питання розвитку іконостасної орнаментики, починаючи від XV і до кінця XVIII ст., є монографія М. Драгана, однак у ній увагу зосереджено лише на оздобленні царських врат.

Новизна наукового дослідження. Вперше запропоновано розглядати введення аркатури в ролі обрамлення ікон іконостасів як спеціальний богословський 
проект. Водночас цей архітектурний елемент в іконостасі мав кілька рівнів символічних смислів.

Виклад матеріалу. Ікони апостольського ярусу в іконостасах до XVII ст. не мали аркового обрамлення, про що свідчать збережені від них ікони XIV-XVI ст. Епістилії з чином моління XIV-XV ст. в якості обрамлень, що розділяють постаті, мають прямокутні живописні рамки чи смужки, намальовані на іконах. У наступному столітті зустрічаються довгі горизонтальні іконостасні ікони, на яких сюжети вже розмежовані золоченими пласкими рамками, подібними до полів ковчега, вкритими гравірованими або тисненими по грунту рослинними мотивами. Однак і ці рамки залишаються прямокутними. Прикладом подібного оформлення $є$ деісусно-апостольський чин 1560-х років з с. Долина, що на Івано-Франківщині. Збережені ікони XV-XVI ст. з чину моління, на яких апостоли зображені на окремих дошках, також не були обрамлені аркатурою. Їхній прямокутний абрис і повністю вкрите живописом тло вказує, що будь-яке накладне облямування, у тому числі й аркове, для них не передбачалося.

Іще одним свідченням того, що в іконостасах XVI ст. аркове обрамлення не використовувалося, є відомий начерк 80-х років XVI ст. іконостаса Успенської церкви Львова, виконаний Мартином Іруневегом в його щоденнику (Ісаєвич 108, 114). Цей малюнок не містить подробиць, але чітко доводить, що в другій половині XVI ст. іконостас міг мати складну конструкцію i багате декоративне оздоблення, однак обрамлення у вигляді аркатури в ньому відсутне.

У цій ситуації поява аркових обрамлень в апостольському ярусі іконостаса П'ятницької церкви Львова 1610-х років виглядає прийомом, поява якого ніяк не пов'язана 3 українською традицією облямування іконостасних ікон. Це нововведення, яке, вочевидь, вперше застосоване саме в іконостасі П’ятницької церкви Львова, відразу було не тільки підтриманим, але й визнано необхідним, оскільки відтоді саме такий принцип організації апостольського ярусу стверджується в Україні. Уже в наступні десятиліття іконостаси Західної України демонструють повне прийняття такої концепції оздоблення: аркатура обрамлює апостолів в іконостасі 1629-1638 р. Успенської церкви Львова, є вона і в іконостасі 1650 р. церкви Святого Духа в Рогатині.
Примітним прикладом ставлення до аркового обрамлення в цей час є епістилій з апостолами 1631 р. (Maszczak 191-92) з Дмитрівської церкви с. Щавник на Лемківщині (сьогодні - Польща). Ця пам'ятка цікава тим, що хоча сам епістилій, як іконостасна ікона, для цього часу є архаїчним, однак він має живописну аркатуру, яка розділяе фігури апостолів. Вочевидь, оформлення нею апостольського ярусу на той період вже вважалося необхідним, навіть якщо різьблене обрамлення не додається.

Іконостаси Наддніпрянщини XVII ст. не збереглися, однак підтвердженням того, що обрамлення аркатурою апостольських ікон швидко стало загальноукраїнською практикою, а не місцевим варіантом оформлення, $\epsilon$ зображення фрагментів іконостасів 3 апостольським ярусом на гравюрах київських видань 1620-х років. Йдеться про гравюру «Висвячення Іоанна Златоуста на пресвітера в Антіохії» в книзі «Бесіди Іоанна Златоуста», виданій 1624 р., та гравюру «Дари» зі Служебника 1629 р. В обох випадках апостольський ярус зображений обрамленим аркатурою.

Зміни, що відбулися в концепції обрамлення апостольського ярусу в українському іконостасі початку XVII ст. можна пояснити, якщо звернутися до витоків іконостаса, а саме - до візантійської вівтарної огорожі та принципу оформлення розміщених в ній ікон.

Як відомо, візантійський темплон з'явився і розвивався як принципово архітектурна конструкція. Ймовірно, найбільш поширеним типом візантійської вівтарної огорожі є їі форма у вигляді кам'яного портика з плитами парапету між колонами i царськими вратами в центрі. Архітектура такої вівтарної огорожі в пізньовізантійський період доповнюється встановленням на архітраві епістилія. Примітно, що епістилій, який є дерев'яною дошкою/дошками, з низкою зображень, мабуть, первинно мислився саме як архітектурна складова огорожі. До такої думки схиляє переважаюча кількість збережених візантійських епістиліїв XII-XV ст., на яких сюжети обрамлені рельєфною або живописною аркатурою. При цьому моделюванню колон в такій аркатурі приділялася особлива увага, що вказує на однозначність їі розуміння як архітектурного мотиву. Щодо ікон намісного ряду в візантійській вівтарній огорожі, то вони отримали архітектур- 
не обрамлення від самого спочатку лише завдяки розміщенню зображень в інтерколумніях. Однак згодом, архітектурне оформлення цих ікон набуває особливого значення, оскільки для намісних ікон могли створюватися додаткові архітектурні обрамлення у вигляді півциркульних арок на колонах, вписаних у простір інтерколумній. Приклад застосування такого прийому зберігся в церкві Св. Георгія в Старо Нагорічано, в Македонії, початок XIV ст. У цілому ж, у пізньовізантійській вівтарній огорожі реальна архітектура нижньої частині разом 3 декоративною аркатурою обрамлень ікон епістилія вгорі - свідчить про прагнення створити єдиний архітектурний образ огорожі. Яскравим прикладом реалізації цієї ідеї є вівтарна огорожа XI-XIV ст. у соборі Торчелло, Італія.

Візантійський принцип організації вівтарної огорожі переходить на Балкани, як основа архітектурної форми дерев'яних іконостасів. Збережені від початку XVII ст. такі іконостаси мають ті ж елементи, які йдуть ще від вівтарної огорожі: колони, встановлені на парапеті, архітрав над ними і епістилій над архітравом (Ћоровић-Љубинковић). Найбільш важлива для нас деталь в їхньому оформленні - це традиція декорування аркатурою епістиліїв. Слід сказати, що візантійська традиція оздоблення епістиліїв аркатурою на Балканах, вочевидь, ніколи не переривалась. Зокрема, збереглося чимало пам'яток XV-XVII ст., передусім деісусних чинів, зображення яких обрамлені аркатурою (Војводић; Поповска-Коробар Иконостасот; Поповска-Коробар Охридско). Однак у характері оформлення балканських епістиліїв, і в оздобленні іконостасів Балкан у цілому, в цей час з'являється нова риса - багате прикрашання їх орнаментикою. Аркатура епістиліїв XVI ст. вже може бути настільки декорована різьбленням, що її архітектурна основа під ним практично зникає, як, зокрема, в епістилії XVI ст. з Афона.

Яскравим прикладом зміни концепції образу іконостаса, в якому провідна роль тепер відведена декору, є іконостас 1611 р. Успенського собору Протата на Афоні. Його композиція в цілому традиційна для візантійської вівтарної огорожі: в намісному ярусі ікони знаходяться в інтерколумніях, ікони верхнього ряду обрамляє аркатура, мірний ритм якої не порушений по всій довжині ярусу. Однак використані архітектурні форми наче тонуть в орнаментальному різьбленні, що покриває всі елементи конструкції. Цей іконостас цілком наочно демонструє, що декорування стає чи не самоціллю. Саме так можна інтерпретувати ведення декількох рядів орнаментальних фризів, над верхнім і нижнім ярусами ікон. Детально розглянувши різьблений декор цього іконостасу, М. Чорович-Лубинкович вважала, що пам'ятка знаменує початок нового етапу в розвиткові балканських різьблених іконостасів, а в його орнаментальних мотивах відчутний вплив ісламського мистецтва й італійського Ренесансу (Ћоровић-Љубинковић 126-27). Водночас, прикрашання різьбленням усіх поверхонь іконостаса, від початку XVII ст., стає характерною рисою не тільки іконостасів на Афоні, а й в цілому на Балканах (Ћоровић-Љубинковић Дуборезни; Ћоровић-Љубинковић Средњевековни). Фактично в XVII ст. балканський іконостас продовжує розвиватися як конструкція, що має традиційну візантійську архітектоніку, але яка рясно, можна сказати, по-східному, орнаментована.

Повертаючись до українських іконостасів XVII ст., зауважимо, що раптове введення аркатури в апостольський ярус i, особливо, її ствердження як основної моделі його оформлення, не може розглядатися як випадковий збіг обставин. Найвірогідніше це був свідомий і добре обдуманий крок, мета якого унаочнити зв'язок українського іконостаса 3 грецькою традицією. Джерелом для запозичення найімовірніше стала балканська, і зокрема афонська, практика оформлення верхніх регістрів ікон в іконостасах. Аркатура, яка ніколи раніше не використовувалася в Україні для обрамлення апостольських ікон, тепер вводиться як недвозначна вказівка на поширений грецький принцип оформлення іконостасів.

Введення аркатури водночас могло мати й іншу мету. У візантійській традиції символіка аркових конструкцій введених в опорядження темплона, пов'язана $з$ уявленнями про ідеальний град та 3 ілюстраціями Апокаліпсису (Hahnloser 106). Важливість цієї архітектурної форми для оформлення візантійських вівтарних огорож пояснює широке використання арок в опорядженні балканських іконостасів і в пізніший час. Отже, символічне значення аркатури в разі введення ㄲï в іконостас уже саме собою привносило есхатологічні смисли. Однак те, 
що аркатура обрамила ікони апостольського ярусу, робило сенс послання ще більш наочним. Тлумачення смислу цього ярусу, як воно розумілося в Україні XVII ст., викладено в книзі Феодосія Софоновича «Виклад о церкві святій». Він пояснює:

Чому Деісуса, тобто Христоса 3 дванадцятьма апостолами, малюють перед вівтарем? Бо вівтар є Маєстат Христовий, тому й Христа на Маєстаті як Судію малюють, а при Ньому дванадцять апостолів, бо їм так сам Христос обіцяв: «коли ... Син Людський засяде на престолі слави Своєї, тоді сядете й ви, що за Мною пішли, на дванадцять престолів, щоб судити». Тому Христа, що сидить як суддя, малюють над вівтарем, щоб ми, на судію Страшного суду дивлячися, думали про себе і зі страхом приступали до Божественних Таїнств...‥ (Софонович 62-3)

3 цього фрагмента зрозуміло: ярус апостолів в іконостасі сприймався як ілюстрація майбутнього Суду Божого, а обрамлення його аркатурою акцентувало увагу на його есхатологічних смислах.

1 Переклад тексту сучасною украӥнською мовою Ю. Мицика.
Висновки. Введення обрамлень у вигляді аркатури для ікон апостольського ярусу створює композиційні паралелі в опорядженні українських іконостасів та іконостасів Балкан. Ця єдність використаних композиційних формул візуально посилює спорідненість українського іконостаса з балканським, а відтак, унаочнює його візантійські витоки.

Акцентуючи есхатологічні смисли апостольського ярусу, аркатура водночас була інструментом його пізнання, оскільки вказувала на зміст обрамленої нею композиції раніше, ніж цю композицію можна було роздивитись. Обрамлення аркатурою апостольських ікон слугувало своєрідним маркером, який вказував на наявність і місце цього ярусу в багаторівневій структурі іконостаса XVII ст.

Перспективи використання результатів дослідження. Основні положення, викладені у статті, $\epsilon$ підгрунтям для подальшого вивчення причин, які зумовили формування композиції українського іконостаса початку XVII ст. та семантики архітектурно-пластичної організації українського іконостаса упродовж XVII-XVIII ст.

\section{Цитовані праці}

Александрович, Володимир. «Мистецтво другої половини XVI - початку XVII ст. Образотворче мистецтво: Скульптура». Історія украӥнського мистецтва: у 5 т. Т. 3. Київ: НАН України, ІМФЕ ім. м. Т. Рильського, 2011. Друк.

Александрович, Володимир. «Мистецтво середини XVII - середини XVIII ст. Образотворче мистецтво: Скульптура». Історія украӥнського мистеитва: у 5 т. Т. 3. Київ: НАН України, ІМФЕ ім. м. Т. Рильського, 2011. Друк.

Војводић, Драган, Милош Живковић. «Деизисни чин из Пиве. Прилог проучавању иконостаса и иконописа у пивском манастиру». Зограф 38 (2014): 203-220. Друк.

Гембарович, Мечислав. «Скульптура та різьблення». Історія украӥнського мистецтва: в 6 т. Т. 3. Київ: УРЕ, 1968. Друк.

Драган, Михайло. Украӥнська декоративна різьба XVI-XVIII cm. Київ: Наукова думка, 1970. Друк.

Ісаєвич, Ярослав. «Найдавніший історичний опис Львова». Жовтень 10 (1980): 105-114. Друк.

Поповска-Коробар, Викторија. «Иконостасот на бигорск иот манастир во XVI-XVII век». Patrimonium. MK 12 (2011): 243-259. Print.

Поповска-Коробар, Викторија. «Охридско-струшки иконописни траги од втората половина на XV век». Patrimonium. MK 7-8 (2010): 300-302. Print.

Софонович, Феодосій, ієромонах. Виклад о иеркві святій. Київ: КМ Академія, 2002. Друк.

Ћоровић-Љубинковић, Мирјана. «Дуборезни иконостаси XVII века на Светој Гори». Хиландарски зборник I (1966): 121-134. Print.

Ћоровић-Љубинковић, Мирјана. Средњевековни дуборез у источним областима Југославије. Београд, 1965. Print.

Hahnloser, Hans, Renato Polacco. «Le oreficerie della Pala d'Oro». La Pala d'oro. Venezia: Canal \& stamperia, 
1994. 81-111. Print.

Maszczak, Maria Teresa. Ikony w zbiorach Muzeum Okręgowego w Nowym Saczu. Nowy Sącz: Muzeum Okręgowe, 2010. Print.

\section{References}

Aleksandrovych, Volodymyr. «Mystetstvo druhoi polovyny XVI - pochatku XVII st. Obrazotvorche mystetstvo: Skulptura». Istoriia ukrainskoho mystetstva: u 5 t. T. 3. Kyiv: NAN Ukrainy, IMFE im. M. T. Rylskoho, 2011. Druk.

Aleksandrovych, Volodymyr. «Mystetstvo seredyny XVII - seredyny XVIII st. Obrazotvorche mystetstvo: Skulptura». Istoriia ukrainskoho mystetstva: u 5 t. T. 3. Kyiv: NAN Ukrainy, IMFE im. M. T. Rylskoho, 2011. Druk.

Vojvodić, Dragan, Miloš Živković. «The Deesis row from Piva: A contribution to the study of the iconostasis and icon painting of the Monastery of Piva». Zoghraf 38 (2014): 203-220. Druk.

Hembarovych, Mechyslav. «Skulptura ta rizblennia». Istoriia ukrainskoho mystetstva: v 6 t. T. 3. Kyiv: URE, 1968. Druk.

Dragan, Mykhailo. Ukrainska dekoratyvna rizba XVI-XVIII st. Kyiv: Naukova dumka, 1970. Druk. Isaievych, Yaroslav. «Naidavnishyi istorychnyi opys Lvova». Zhovten 10 (1980): 105-114. Druk.

Popovska-Korobar, Viktorija. "The iconostasis of bigorski monastery in the 16th - 17th centuries. Theoretical reconstruction". Patrimonium. MK 12 (2014): 243-259.

Popovska-Korobar, Viktorija. "Icon painting traces from ohrid and struga from the second half of the 15th century". Patrimonium. MK 7-8 (2010): 300-302.

Sofonovych, Feodosii, iieromonakh. Vyklad o tserkvi sviatii. Kyiv: KM Akademiia, 2002. Druk.

Corović-Ljubinković, Mirjana. «Duborezni ikonostasi XVII veka na Svetoj Gori», Hilandarski zbornik T. I (1966): 121-134. Druk.

Corović-Ljubinković, Mirjana. Srednjevekovni duborez u istočnim oblastima Jugoslavije. Beoghrad, 1965. Druk. Hahnloser, Hans, Renato Polacco. "Le oreficerie della Pala d'Oro". La Pala d'oro. Venezia: Canal \& stamperia, 1994. Druk.

Maszczak, Maria Teresa. Ikony w zbiorach Muzeum Okręgowego w Nowym Sączu. Nowy Sącz: Muzeum Okręgowe, 2010. Druk.

Подано до редакиії 03.12.2018

Рецензенти:

Коренюк Ю. О. - кандидат мистецтвознавства;

Пучков А. О. - доктор мистецтвознавства, професор. 